\title{
26 Research Square \\ Long-term Economic Effects of Aridification on the GDPs of Africa and Asia
}

Maurizio Malpede ( $\nabla$ maurizio.malpede@unibocconi.it )

Bocconi University

Marco Percoco

Bocconi University

Social Sciences - Article

Keywords: human-induced desertification, Africa, Asia, economic growth, GDP

Posted Date: April 6th, 2021

DOI: https://doi.org/10.21203/rs.3.rs-396982/v1

License: (c) (i) This work is licensed under a Creative Commons Attribution 4.0 International License.

Read Full License 


\section{Abstract}

We examine the effects of human-induced desertification on economic growth by exploiting a $56 \mathrm{~km}$-by$56 \mathrm{~km}$ grid-cell global dataset on the annual frequency from 1990-2015. We find that areas that experienced large soil aridification are associated with a reduction in GDP per capita. Our results indicate that from 1990-2015, aridification reduced the GDPs of African and Asian countries by $12 \%$ and $2.7 \%$, respectively. Our estimates are robust to adding higher-order terms of geo-climatic variables and controlling for country-specific linear trends, which allows us to project future costs of desertification. Our findings show that desertification will generate losses in GDP growth by $16 \%$ and $6.7 \%$ in Africa and Asia, respectively.

\section{Introduction}

Approximately 52 million square kilometers of the Earth's surface are dryland areas, defined as zones where the total amount of precipitation is balanced by the evaporation of water from land and the natural transpiration from plants [1]. This "right" balance between rainfall and water evaporation is pivotal in maintaining biological productivity. However, climate change is steadily modifying this equilibrium, with dramatic consequences for liveability and food availability in many areas worldwide.

According to the Intergovernmental Panel on Climate Change 2019 [2], in 2015, about 500 million people lived within areas that had experienced desertification between the 1980s and 2000s. Desertification is defined as land degradation in arid, semi-arid, and dry sub-humid regions caused by many factors, including climatic variations and human activities. This situation is expected to worsen in future decades because the population vulnerable to habitat degradation, including desertification, is estimated to increase in intervals (178-277) of a million people by 2050, depending on the global climate scenario. Moreover, Asia and Africa are expected to have the highest number of vulnerable people [2]. Despite these projections, there is little knowledge about the economic effects of desertification in the short and longterm $[3,4,5]$.

The goal of this study is to assess the economic effects of climate-induced soil aridification. We assembled a panel dataset of more than 66,000 grid cells with almost global coverage of the 26 years between 1990 and 2015. We combined annual grid-level data on GDP per capita [7] with climate variables such as precipitation, average temperature, and potential evo-transpiration. The combination of rainfall and potential evo-transpiration enabled us to use the Aridity Index (Al) to measure desertification [8].

We assess the relationship between annual variations in the Al and GDP per capita using econometric panel models. Our findings are summarised as follows:

i. There is a significant grid-level relationship between Al and GDP per capita. According to our benchmark specification, a one standard deviation shock to the $\mathrm{Al}$ is associated with a decline in the GDP per capita between $1.9 \%$ and $4.1 \%$. The African continent exhibits the highest decrease, with a total cost of 14\% in GDP per capita, caused by soil aridification during 1990-2015. 
ii. Aridification has a more significant effect compared with precipitation and temperature alone. Our baseline estimates showed that a one standard deviation shock in annual precipitation levels affected GDP per capita by between $1.6 \%$ and $2.5 \%$. In contrast, a standard deviation shock in temperature levels caused decreases in GDP per capita by $0.5-2.9 \%$.

iii. The effects are higher in humid areas of the world (i.e., characterised by higher precipitation and lower evapotranspiration) than in arid areas. Furthermore, we find that lower-income countries are more affected by desertification compared with higher-income countries.

iv. The effects of precipitation alone do not entirely explain the economic impact of climate shocks. We find that although most areas in the southern hemisphere experienced an increase in rainfall from 1990-2015, they showed a decline in Al, which partly explains lower GDPs per capita.

v. Finally, based on a recent dataset on future projections of precipitation and potential evapotranspiration [9], we predict that desertification would cost as much as $10 \%$ in terms of GDP per capita in Sub-Saharan Africa by 2079. These results are obtained using a baseline scenario that assumed a peak in greenhouse gas emissions by 2040 , followed by a decline throughout the $21 \mathrm{st}$ century.

\section{The Geography Of Desertification}

"Desertification" was first defined as "land degradation in arid, semi-arid and dry sub-humid areas resulting from a range of factors, including climatic variations and human activities" [10]. Major climatic factors leading to desertification include climatic variables such as spatial and temporal distributions of precipitation, increases in land surface albedo, drought events, sudden and high-intensity rainfall, high temperatures, and high wind speeds [11].

Based on future carbon emissions scenarios, scientific literature showed that dryland areas would increase between $11 \%$ and $23 \%$ by the end of the present century in relation to the 1961-1990 baseline $[12,13,14]$. This expansion of drylands would reduce carbon sequestration and enhance regional warming, resulting in warming trends over present drylands double those over humid regions. Global warming and the rapidly growing human population will exacerbate the risk of land degradation and desertification in the drylands of developing countries. Recently it was shown that that aridity is projected to decrease (i.e., areas would become drier) because of anthropogenic climate change [15]. However, accomplishing the $1.5^{\circ} \mathrm{C}$ temperature goal would substantially reduce the likelihood that large regions would face substantial aridification and its effects [12].

Figure 1 shows that despite the declining trend in total precipitation (Panel A) in most areas of the world, particularly in Africa and the Middle East, large parts of Latin America and South-East Asia have experienced increased precipitation compared with their historical mean. Nevertheless, zones that have experienced increases in precipitation might also have become increasingly arid. Panel B in Fig. 1 shows that the increases in precipitation levels experienced in Latin America and Southeast Asia have been accompanied by higher evaporation levels. 
To better measure dryness, the total amount of precipitation must be divided by the soil's potential evapotranspiration (PET), which is a measure of the "drying power" of the atmosphere in removing water from land surfaces by evaporation [16]. Higher levels of evapotranspiration lead to more arid land at a given level of precipitation. In particular, PET is calculated by the method proposed by Penman in 1948 [17], and different variables are considered, such as atmospheric humidity, solar radiation, and wind. These variables are affected by climate change [18]. This ratio is defined as the Aridity Index (Al). The Al is a simple but convenient measure of the actual water availability of the land. Recently, the effects of rainfall and potential evapotranspiration soil moisture on distinct regions of the world were examined [19]. Their findings showed a significant difference between precipitation and aridity: if PET is larger than $P$, then the climate is arid.

To operationalise the concept of desertification, five types of arid lands or drylands were classified [20]:

- Hyper-arid $(\mathrm{Al}<0.05)$

- Arid $(0.05<\mathrm{Al}<0.2)$

- Semi-arid $(0.2<\mathrm{Al}<0.5)$

- Dry sub-humid $(0.5<\mathrm{Al}<0.65)$

- Humid (Al>0.65)

The process in which the biological activity of drylands decreases is called "desertification", which corresponds to lower Al levels. During the last 40 years, the process of desertification has accelerated by more than 30 times its historical rate [21]. The principal factors of soil aridification are farming and human activities, such as clearing away trees and other vegetation. Hence, an increasing amount of literature focuses on the differences between rainfall and aridity. In this regard, a recent study has distinguished between droughts, which are transient regional extreme phenomena typically defined as departures from a local climatological norm that is presumed known, and so-called "background" dryness [22]. In addition to being a function of precipitation, the latter depends on how fast water evaporates. Indeed, a primary consequence of climate change is that average rainfall is predicted to increase in some areas of the world. However, evaporation is also expected to increase because of warmer temperatures. As a result, the net effects of the two forces on aridity are uncertain.

Figure 2 shows the global distributions of percentage changes in the Aridification Index (Al) measured by the difference between the present-day (1990-2015) and the historical average (1900-1980). As shown in Fig. 2, the areas that are the most affected by desertification are primarily located in continental Europe, Africa, and South-East Asia. The Al in Africa decreased from an average of 0.25 for the period 1990-2015 to 0.23 compared with the period from 1900-1980. The overall change was equal to approximately $8 \%$. However, areas on the west side of the continent showed aridification that had exceeded $50 \%$. Similarly, the average Al in Southeast Asia had decreased by 3\% compared with the period from 1980-1990, and areas in the west of China and Mongolia showed that aridification had increased by $25 \%$. 


\section{Results}

Our benchmark estimates indicated that higher Al values are positively associated with GDP per capita. Moreover, the effects are more significant in less developed areas of the world. To confirm our estimates, we explored the sensitivity of our estimates to several models, aridity classes, and income groups.

This result contrasts a recent study that found that the relationship among temperature, precipitation, and economic growth was globally generalisable to agricultural and non-agricultural activity in rich and developing countries [23].

Our results showed that grid-level income per capita was non-linear and concave according to the Al. This finding indicates that income increases with higher water availability of the soil, whereas it decreases with excessive precipitation or too little soil transpiration caused by extreme heat and humidity. This nonlinear effect of aridity on income per capita is in line with the estimates shown for temperature shocks (Fig. 3) [23]. In particular, we find that above a threshold of approximately 0.65 , a marginal variation in $\mathrm{Al}$ did not have economic effects.

However, our estimates show that the areas most affected by soil aridification are located on the African and Asian continents. As a result, these continents will pay the highest price in terms of GDP loss.

This finding is consistent with the "opportunity cost" mechanism related to local agricultural production. We argue that the adverse economic effects of soil aridification are partly due to less efficient crops. For example, if a particular area experiences substantially less precipitation in a given year (or a higher PET), the crop yield could be negatively affected, which would lead to economic losses. Several theoretical and empirical studies have offered insights relevant to our proposed interpretation $[23,24,25,26]$.

Based on the results in Appendix B and shown in Fig. 3, it is possible to evaluate the average annual economic impact of desertification from 1990 to 2015. Figure 4 shows the average annual GDP per capita loss in Africa (Panel A) and Asia (Panel B). We estimate that during the last 25 years, in some areas on the African continent, climate-induced soil aridification had decreased the GDP per capita by more than $12 \%$.

Our results show a slight but significant positive relationship between Al and GDP per capita worldwide. However, the economic effects of the decreased Al were more pronounced in Asia and Africa. We estimate that the cumulative reduction in Al between

1990 and 2015 has negatively affected the Asian GDP per capita by between one and six percentage points, and the African GDP per capita between 9 and 16\%.

The results of the association between Al and GDP were used to project the costs of future desertification patterns. We first computed the future grid-cell projections of the Al by using annual precipitation and potential evapotranspiration data drawn from the most recent CMCC-BioClimlnd [5]. These projections are obtained from a variety of earth system models and two representative concentration pathways (i.e., 
RCP 4.5 and RCP 8.5), which are part of the World Climate Research Programme's Coupled Model Intercomparison Project phase 5 (CMIP5). In particular, we considered the RCP 4.5 emissions scenario. RCP 4.5 assumes a peak in greenhouse gas emissions between 2010 and 2030, followed by a decline throughout the 21st century. For the period 2021-2040, the WorldClim 2.1 database forecasts an increase in temperature between 0.93 and $1.27^{\circ} \mathrm{C}$, with precipitation predicted to increase between 10 and 30 percentage points in the northern hemisphere while decreasing between 10 to $40 \%$ in the southern hemisphere, depending on the Shared Socioeconomic Pathway (SSP) considered [27]. Conversely, the evapotranspiration is estimated to increase between 0.4 and $3.8 \%$ for $2021-2040$ compared to the present-day mean (2011-2020) [28].

In our historical sample (1900-1980), the average Al was 0.489 , which declined to 0.479 during the present day (1990-2015). It is predicted to be 0.438 in the projected period from 2040-2079. This result indicates that the average cell would experience rainfall shortages comparable to the present-day mean. Specifically, 17,926 grid cells were arid or hyper-arid (i.e., $\mathrm{Al}<0.2$ ) during the historical period. However, this number was projected to increase to 20,998 in the period from 2040-2079. Based on this projection, more than 2,000 grid cells will become arid in the future (i.e., approximately 5 million $\mathrm{km}^{2}$ or $3 \%$ of the world's land surface). Figure 5 shows the grid-cell differences in percentages between the projected $\mathrm{Al}$ and the present-day mean for the world, Africa, and Asia.

In Fig. 7 (right), panel B presents the estimation of the effects of future Al variations on GDP per capita growth between the present day and 2079 under the baseline RCP 4.5 scenario. The patterns are similar to those in recent decades. Future variations in the Al resulted in a total cost of $6.7 \%$ in GDP per capita growth in Asia and about 15\% in Africa.

\section{Conclusion}

The results of our study showed that climate-induced aridification was associated with a reduction in GDP per capita. Although the decline was high in Asia (-2.7\%), we find that the effects of desertification were more significant in poor African countries that relied on agriculture (-12.74\% of GDP during the period 1990-2015). We also showed that by 2079, aridification would cost African and Asian countries $16 \%$ and $6.7 \%$, respectively.

Overall, our study provides a first step in understanding the effects of human-induced climate aridification on the economic development of areas that rely predominantly on agriculture. Moreover, the findings indicate that instead of precipitation, the Aridity Index should be used to determine the economic effects of climate change.

\section{Declarations}

Declarations 
Note

Secular data on precipitation and PET were retrieved from Fu et al. (2016),

\section{Declarations}

\section{Note}

Secular data on precipitation and PET used to construct the Al were retrieved from the National Centre for Atmospheric Science (2020) [30].

\section{Declarations}

\section{Note}

Grid-level data used to construct the Aridity Index were retrieved from the National Centre for Atmospheric Science (2020), and grid-level GDPs per capita were adopted from Kummu et al. (2018) [7]. The parameters used to draw the functions are shown as estimates in Table 2 in Appendix B.

\section{Declarations}

\section{Note}

The areas in red indicate the highest impact of the Aridity Index on GDP per capita from 1990-2015.

\section{References}

1. Sidahmed, A. E. (2018). Recent trends in drylands and future scope for advancement. In Climate Variability Impacts on Land Use and Livelihoods in Drylands (pp. 21-57). Springer, Cham.

2. Intergovernmental Panel on Climate Change (IPCC), Sixth Assessment Report (2019). AR6 Climate Change 2021: Impacts, Adaptation and Vulnerability.

3. Carleton, T. A., \& Hsiang, S. M. (2016). Social and economic impacts of climate. Science, 353(6304).

4. Dell, M., Jones, B. F., and Olken, B. A. (2008). Climate change and economic growth: Evidence from the last half century. Technical report, National Bureau of Economic Research.

5. Dell, M., Jones, B. F., and Olken, B. A. (2012). Temperature shocks and economic growth: Evidence from the last half century. American Economic Journal: Macroeconomics, 4(3):66-95.

6. Harari, M. and Ferrara, E. L. (2018). Conflict, climate, and cells: a disaggregated analysis. Review of Economics and Statistics, 100(4):594-608.

7. Kummu, M., Taka, M., and Guillaume, J. H. (2018). Gridded global datasets for gross domestic product and human development index over 1990-2015. Scientific data, 5:180004. 
8. Middleton, N., \& Thomas, D. (1997). World atlas of desertification. ed. 2. Arnold, Hodder Headline, PLC.

9. Noce, S., Caporaso, L., \& Santini, M. (2020). A new global dataset of bioclimatic indicators. Scientific Data, 7(1), 1-12.

10. Ma, H., \& Zhao, H. (1994). United Nations: Convention to combat desertification in those countries experiencing serious drought and/or desertification, particularly in Africa. Int. Legal Mater, 33, 13281382.

11. Ogallo, L. and Gbeckor-Kove, N. (1989). Drought and desertification. WMO.

12. Huang, J., Yu, H., Guan, X., Wang, G., and Guo, R. (2016). Accelerated dryland expansion under climate change. Nature Climate Change, 6(2):166-171.

13. Park, C.-E., Jeong, S.-J., Joshi, M., Osborn, T. J., Ho, C.-H., Piao, S., Chen, D., Liu, J., Yang, H., Park, H., et al. (2018). Keeping global warming within $1.5 \mathrm{c}$ constrains emergence of aridification. Nature Climate Change, 8(1):70.

14. Hsiang, S. M. (2010). Temperatures and cyclones strongly associated with economic production in the Caribbean and central America. Proceedings of the National Academy of Sciences, 107(35):15367-15372.

15. Moore, F. C. and Diaz, D. B. (2015). Temperature impacts on economic growth warrant stringent mitigation policy. Nature Climate Change, 5(2):127.

16. Kirkham, M. B. (2014). Principles of soil and plant water relations. Academic Press.

17. Penman, H. L. (1948) Natural evaporation from open water, bare soil and grass, Proc. ROY. SOC. A $193,120-146$

18. Salem, B. et al. (1989). Arid zone forestry: a guide for field technicians. Number 20. Food and Agriculture Organization (FAO).

19. Cowley, G. S., Niemann, J. D., Green, T. R., Seyfried, M. S., Jones, A. S., \& Grazaitis, P. J. (2017). Impacts of precipitation and potential evapotranspiration patterns on downscaling soil moisture in regions with large topographic relief. Water Resources Research, 53(2), 1553-1574.

20. Cherlet, M., Hutchinson, C., Reynolds, J., Hill, J., Sommer, S., von Maltitz, G. (Eds.), World Atlas of Desertification, Publication Office of the European Union, Luxembourg, 2018.

21. Burrell, A. L., Evans, J. P., \& De Kauwe, M. G. (2020). Anthropogenic climate change has driven over 5 million km2 of drylands towards desertification. Nature communications, 11(1), 1-11.

22. Sherwood, S. and Fu, Q. (2014). A drier future? Science, 343(6172):737-739.

23. Burke, M., Hsiang, S. M., and Miguel, E. (2015). Global non-linear effect of temperature on economic production. Nature, 527(7577):235-239.

24. Parry, M. L. (2019). Climate change and world agriculture. Routledge.

25. Dell, M., Jones, B. F., and Olken, B. A. (2014). What do we learn from the weather? the new climateeconomy literature. Journal of Economic Literature, 52(3):740-98. 
26. Tol, R. S. (2009). The economic effects of climate change. Journal of economic perspectives, 23(2):29-51.

27. Fick, S.E. and R.J. Hijmans, 2017. WorldClim 2: new $1 \mathrm{~km}$ spatial resolution climate surfaces for global land areas. International Journal of Climatology 37 (12): 4302-4315.

28. Wang, L., Wang, S., Zhang, L., Salahou, M. K., Jiao, X., \& Sang, H. (2020). Assessing the Spatial Pattern of Irrigation Demand under Climate Change in Arid Area. ISPRS International Journal of GeoInformation, 9(9), 506.

29. Arellano, M. and Bond, S. (1991). Some tests of specification for panel data: Monte Carlo evidence and an application to employment equations. The review of economic studies, 58(2):277-297.

30. Fu, Q., Lin, L., Huang, J., Feng, S., and Gettelman, A. (2016). Changes in terrestrial aridity for the period 850-2080 from the community earth system model. Journal of Geophysical Research: Atmospheres, 121(6):2857-2873.

31. Harris, I., Osborn, T. J., Jones, P., and Lister, D. (2020). Version 4 of the cru ts monthly high-resolution gridded multivariate climate dataset. Scientific data, 7(1):1-18.

32. National Center for Atmospheric Science (2020). The CEDA Archive. /http://www. archive.ceda.ac.uk/. [Online; accessed 9-July-2020].

\section{Figures}


Panel A: Precipitation changes

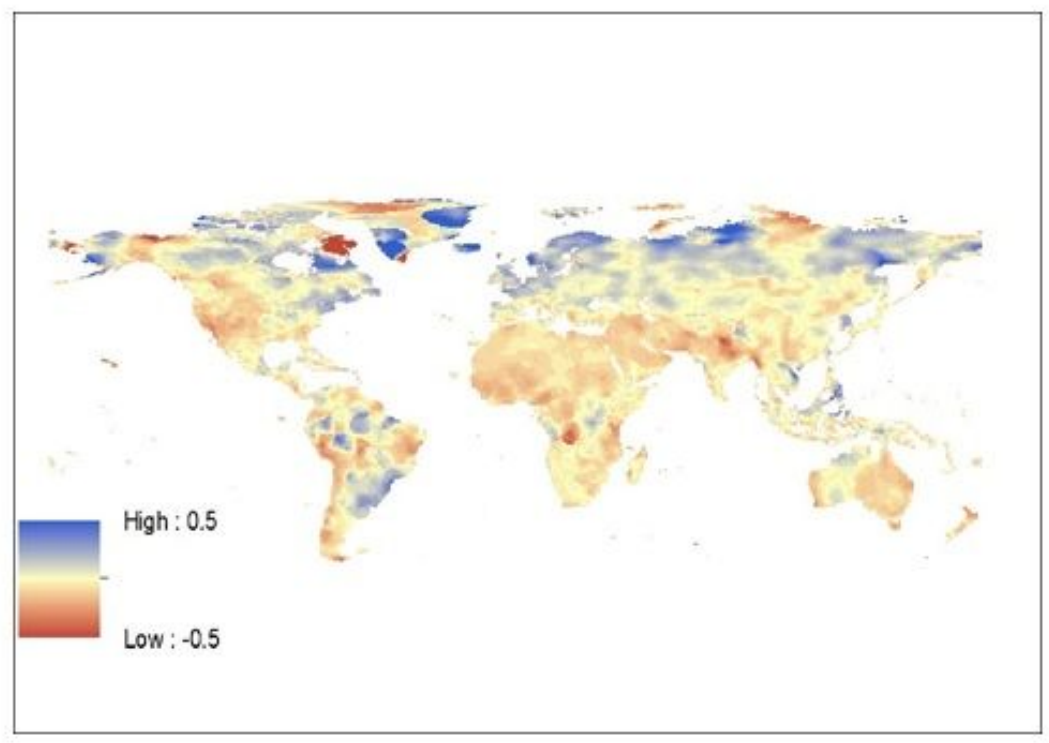

Panel B PET changes

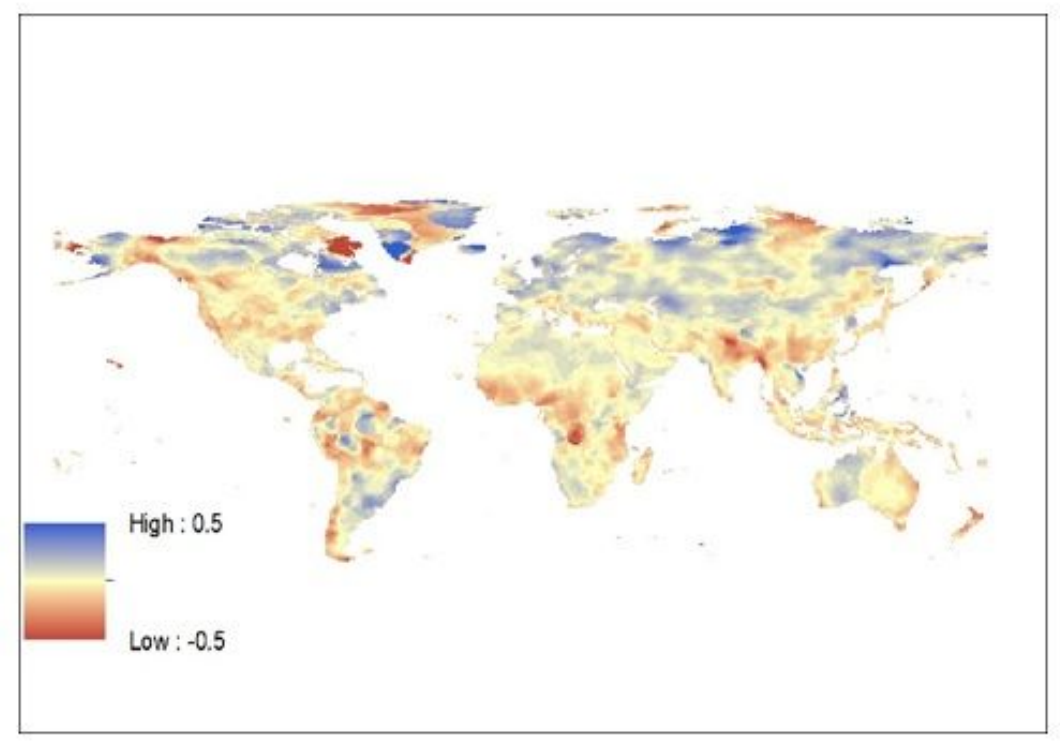

Note. Secular data on precipitation and PET were retrieved from Fu et al. (2016),

\section{Figure 1}

Global distributions of percentage changes (\%) in (a) precipitation and (b) PET between the present day (2000-2015) and the historical average (1900-1980) Note: The designations employed and the presentation of the material on this map do not imply the expression of any opinion whatsoever on the part of Research Square concerning the legal status of any country, territory, city or area or of its 
authorities, or concerning the delimitation of its frontiers or boundaries. This map has been provided by the authors.

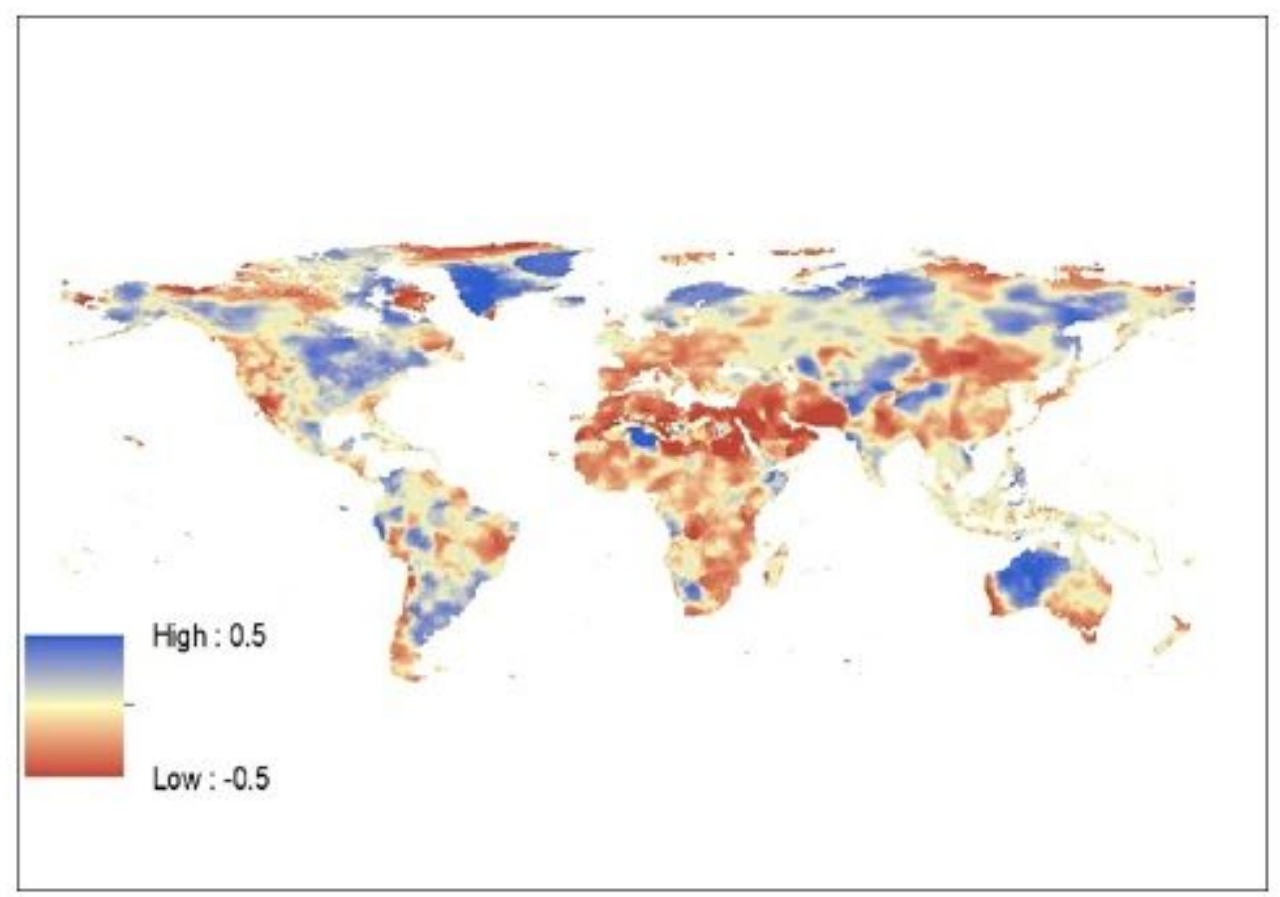

Note. Secular data on precipitation and PET used to construct the AI were retrieved from the National Centre for Atmospheric Science (2020) [30].

\section{Figure 2}

Global distributions of percentage changes (\%) in the Al between the present day (2000-2015) and the historical average (1900-1980) Note: The designations employed and the presentation of the material on this map do not imply the expression of any opinion whatsoever on the part of Research Square concerning the legal status of any country, territory, city or area or of its authorities, or concerning the delimitation of its frontiers or boundaries. This map has been provided by the authors. 


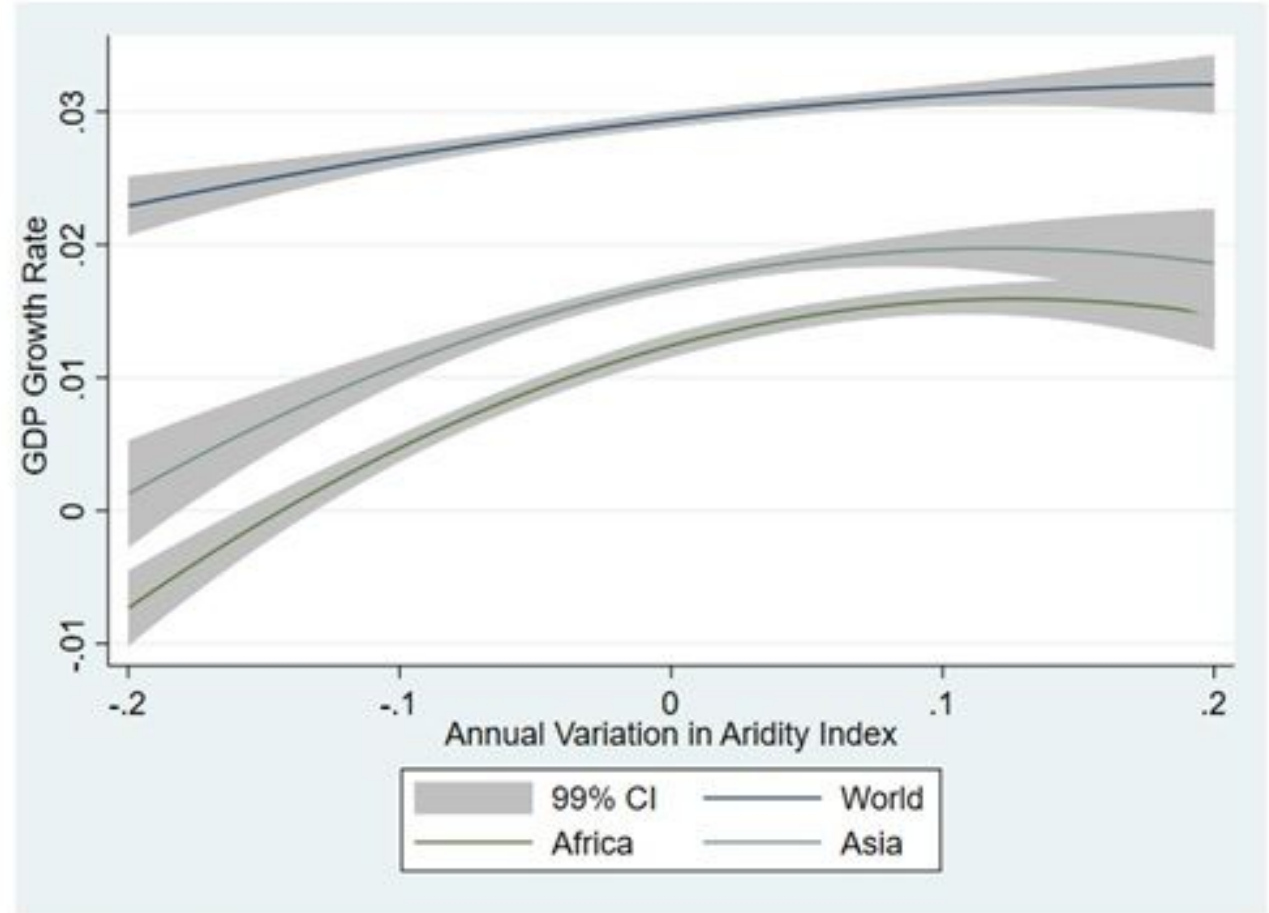

Note. Grid-level data used to construct the Aridity Index were retrieved from the National Centre for Atmospheric Science (2020), and grid-level GDPs per capita were adopted from Kummu et al. (2018) [7]. The parameters used to draw the functions are shown as estimates in Table 2 in Appendix B.

\section{Figure 3}

Relationship between grid-cell annual variations in Aridity Index and GDP per capita from 1990-2015 in World, Africa, and Asia. 
Panel A: Africa

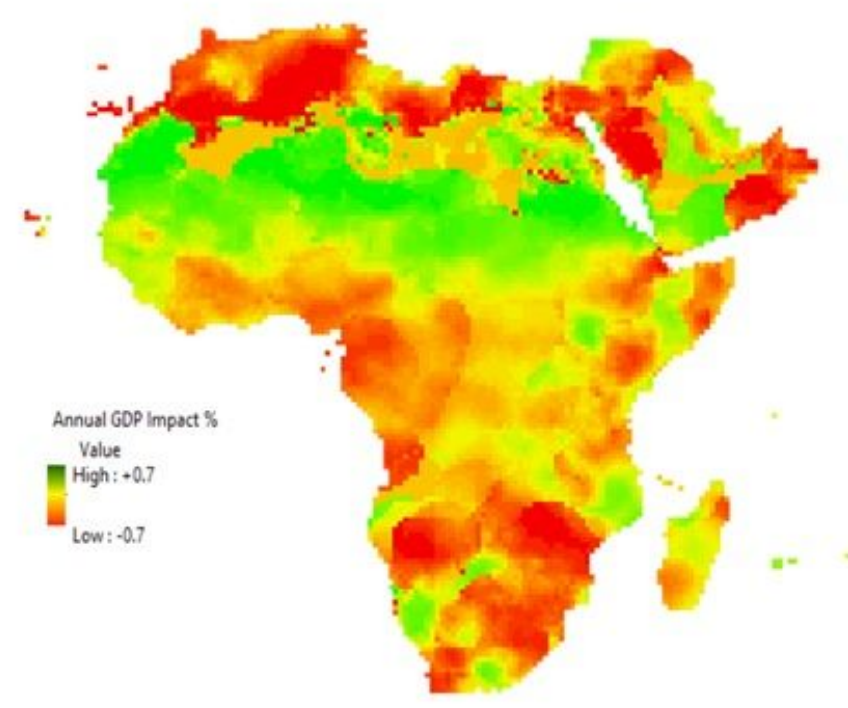

Panel B: Asia

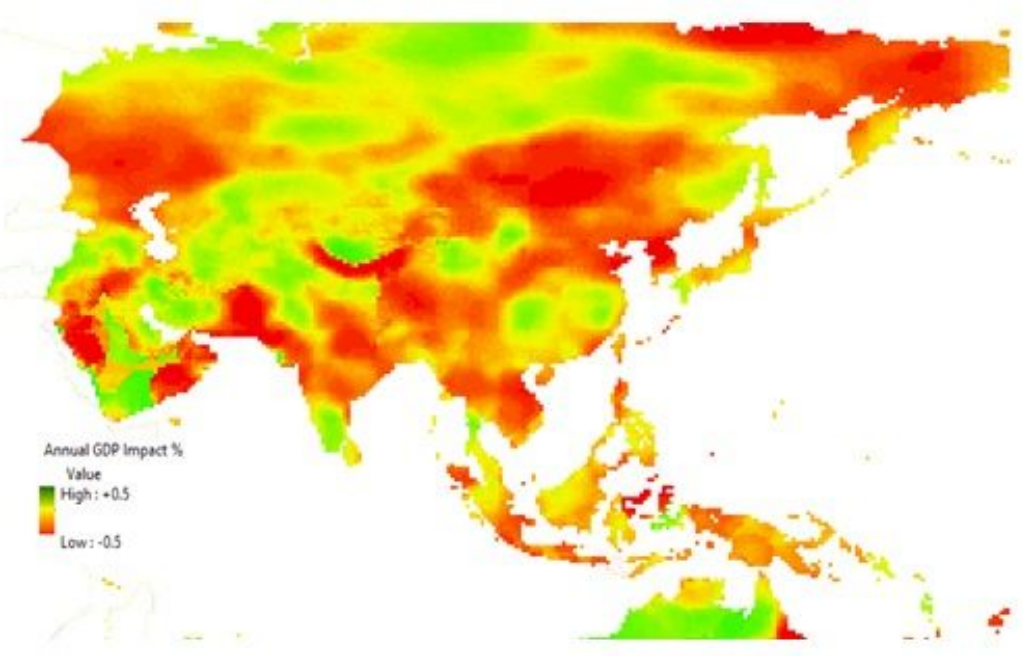

Note. The areas in red indicate the highest impact of the Aridity Index on GDP per capita from 1990-2015.

\section{Figure 4}

Average annual effects of Aridity Index on GDP per capita from 1990-2015 Note: The designations employed and the presentation of the material on this map do not imply the expression of any opinion whatsoever on the part of Research Square concerning the legal status of any country, territory, city or area or of its authorities, or concerning the delimitation of its frontiers or boundaries. This map has been provided by the authors. 
Panel A: World

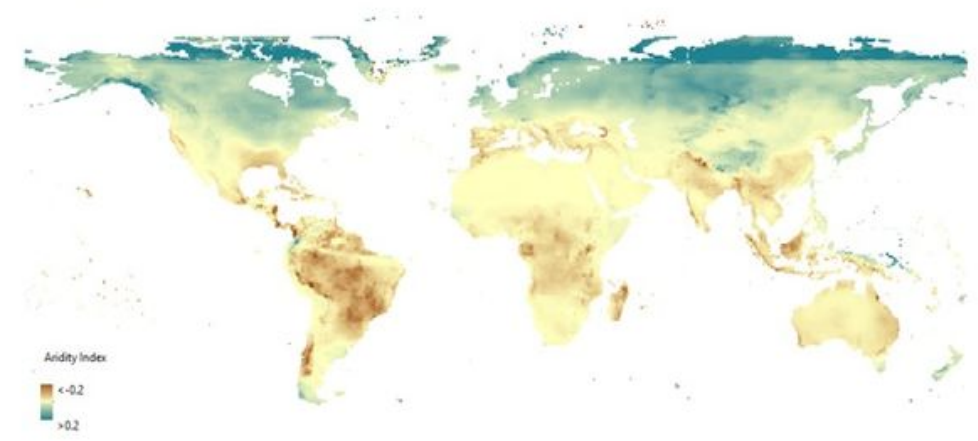

Panel B: Africa

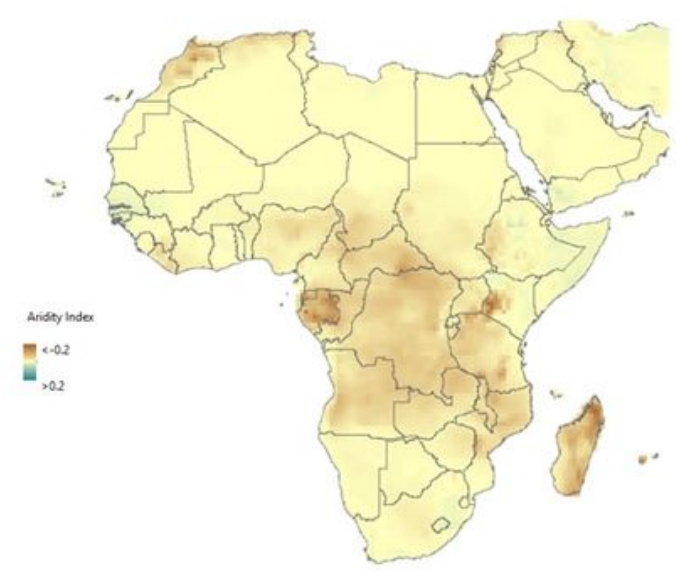

Panel C: Asia

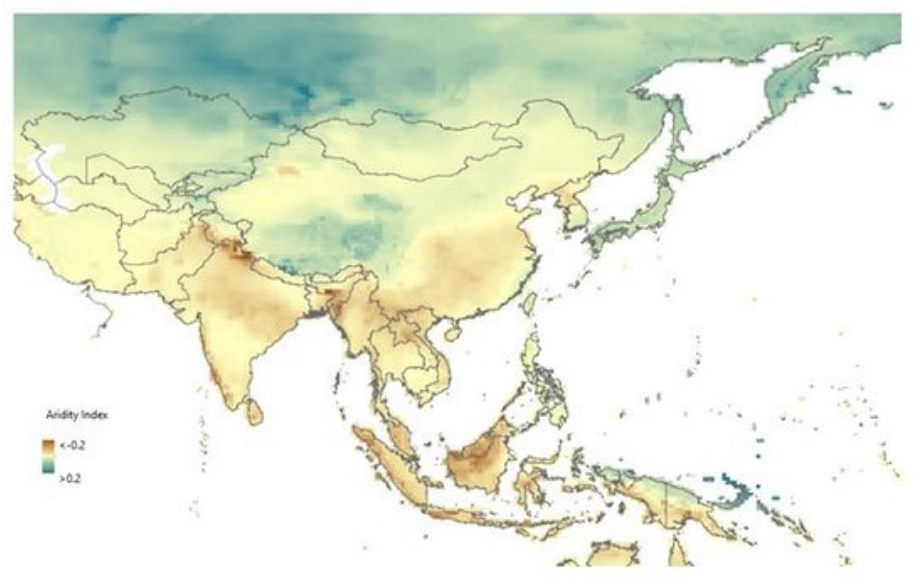

\section{Figure 5}

Distributions of percentage changes (\%) in the Aridity Index, shown as the difference between the period 2040-2079 and the present day (1990-2015). Future data on precipitation and PET used to construct the Al were retrieved from the CMCC-BioClimlnd [9]. The dark brown colour indicates areas that are projected to be most affected by desertification. Note: The designations employed and the presentation of the material on this map do not imply the expression of any opinion whatsoever on the part of 
Research Square concerning the legal status of any country, territory, city or area or of its authorities, or concerning the delimitation of its frontiers or boundaries. This map has been provided by the authors.

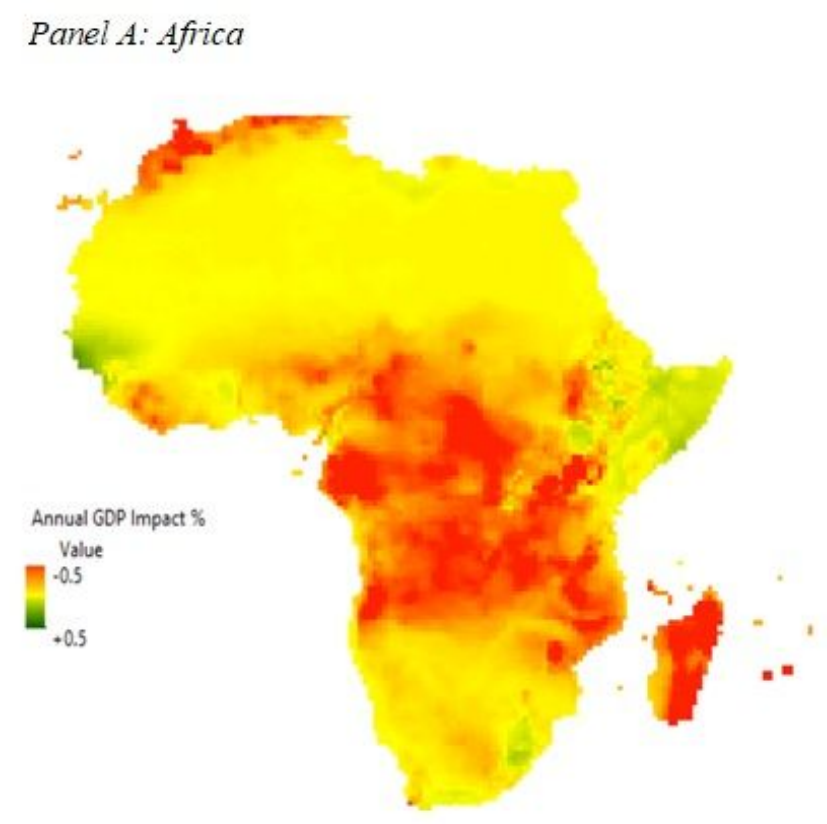

Panel B: Asia

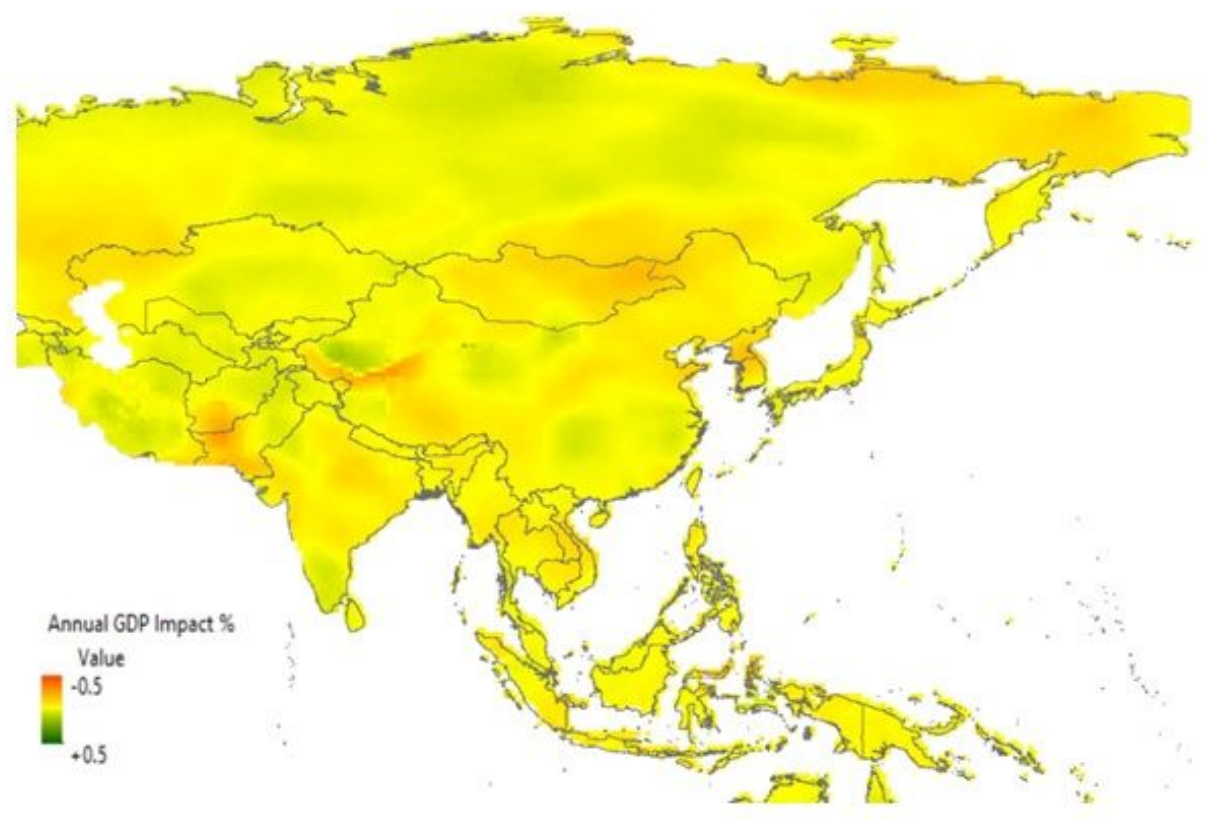

Figure 6

Average annual effects of Aridity Index on GDP per capita 2040-2079 (CMCC-BioClimlnd - RCP 4.5 Projections). Future data on precipitation and PET used to construct the Al were retrieved from the CMCCBioClimlnd [9]. Note: The designations employed and the presentation of the material on this map do not 
imply the expression of any opinion whatsoever on the part of Research Square concerning the legal status of any country, territory, city or area or of its authorities, or concerning the delimitation of its frontiers or boundaries. This map has been provided by the authors.

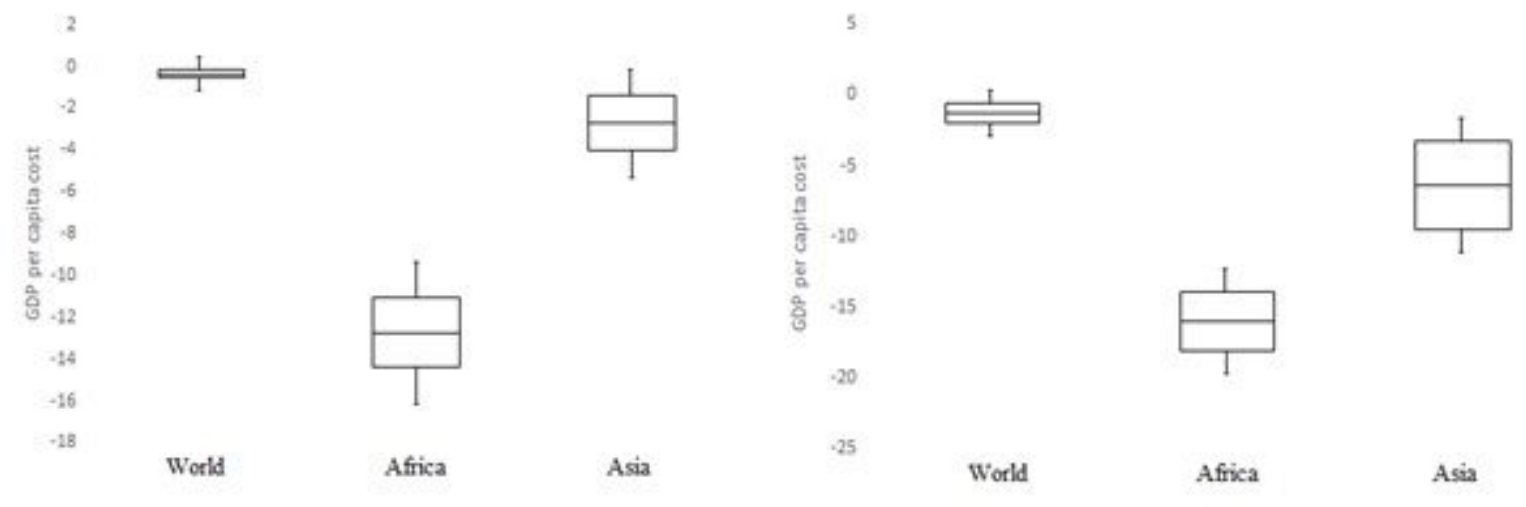

Figure 7

GDP per capita cost due to soil aridification between 1990 and 2015 (left) and between the present day and 2079 in the world, Africa, and Asia. Future data on precipitation and PET used to construct the AI were retrieved from the CMCC-BioClimlnd [9].

\section{Supplementary Files}

This is a list of supplementary files associated with this preprint. Click to download.

- SupplementaryMaterial.docx 